\title{
Marinas may act as hubs for the spread of the pseudo-indigenous bryozoan Amathia verticillata (Delle Chiaje, 1822) and its associates
}

\author{
Agnese Marchini ${ }^{1}$, Jasmine Ferrario ${ }^{1}$, Dan Minchin ${ }^{2,3}$ \\ ${ }^{1}$ Department of Earth and Environmental Sciences, University of Pavia, Via S. Epifanio 14, 27100 Pavia, Italy. \\ E-mail: agnese.marchini@unipv.it \\ ${ }^{2}$ Marine Organism Investigations, Marina Village, Ballina, Killaloe, Co Clare, Ireland. \\ ${ }^{3}$ Marine Science and Technology Centre, Klaipeda University, Klaipeda, Lithuania.
}

\begin{abstract}
Summary: The spaghetti bryozoan Amathia verticillata, formerly known as Zoobotryon verticillatum, was first described in 1822 from Naples, Italy, although this species was already present in 1807 at Cadiz, Spain. This ctenostome has long been considered a native species in the Mediterranean Sea but it has recently been suggested to be of Caribbean origin. It is most likely to have been introduced by vessels as hull fouling. This pseudo-indigenous species, i.e. a non-indigenous species (NIS) having been perceived to be native, has been found in several marinas and harbours within the Mediterranean Sea. In November 2014, this bryozoan species was abundant in the La Grande Motte marina on the south coast of France. Several thousand colonies were estimated to be present within this marina attached to the floating pontoon units that supported a floating boardwalk. Of the berthed craft examined, $31 \%$ were fouled with this species, and it was occasionally a prominent fouling species. Several macroinvertebrate species were associated with A. verticillata colonies, including some NIS, Paracerceis sculpta, Paranthura japonica and Caprella scaura, that are recorded for the first time from the Mediterranean coast of France. A. verticillata might support their transfer elsewhere by providing a habitat and substrate when attached to vessel hulls.
\end{abstract}

Keywords: introduced species; fouling organisms; associated species; ship hulls; shipping; marinas; pontoons.

Los puertos deportivos como centros para la difusión del briozoo pseudoindígeno Amathia verticillata (Delle Chiaje, 1822) y sus asociados

Resumen: El briozoo espagueti Amathia verticillata, anteriormente conocido como Zoobotryon verticillatum, fue descrito por primera vez en 1822 en Nápoles, Italia, aunque esta especie ya estaba presente en 1807 en Cádiz, España. Este ctenostomado ha sido considerado por mucho tiempo como una especie nativa del Mar Mediterráneo, pero se ha sugerido recientemente que es originario del Caribe. Es probable que haya sido introducido incrustado en los cascos de los barcos Esta especie pseudoindígena, es decir, una especie introducida que ha sido percibida como nativa, se ha encontrado en varios puertos comerciales y deportivos del Mar Mediterráneo. En noviembre de 2014, esta especie de briozoo era abundante en el puerto deportivo de La Grande Motte en la costa sur de Francia. Se estimaron varios miles de colonias presentes en este puerto, adheridas a las unidades de pontones flotantes que sostienen el paseo marítimo flotante. El treinta y uno por ciento de los barcos atracados, examinados en el puerto deportivo, estaban incrustados con esta especie, cuyo aspecto algunas veces fue una sola incrustación prominente. Varias especies de macroinvertebrados se asociaron con las colonias del A. verticillata, incluyendo algunas especies introducidas que se registran por primera vez en la costa Mediterránea de Francia: Paracerceis sculpta, Paranthura japonica y Caprella scaura. Este briozoo podría ayudar a la transferencia de diferentes macroinvertebrados a otros lugares, pues proporciona un hábitat y un substrato cuando está adherido a los cascos de los barcos.

Palabras clave: especies introducidas; organismos incrustantes; especies asociadas; casco del barco; navegación; puertos deportivos; pontones.

Citation/Como citar este artículo: Marchini A., Ferrario J., Minchin D. 2015. Marinas may act as hubs for the spread of the pseudo-indigenous bryozoan Amathia verticillata (Delle Chiaje, 1822) and its associates. Sci. Mar. 79(3): 355-365. doi: http://dx.doi.org/10.3989/scimar.04238.03A

Editor: X. Turon.

Received: March 12, 2015. Accepted: May 22, 2015. Published: September 9, 2015.

Copyright: (C) 2015 CSIC. This is an open-access article distributed under the Creative Commons Attribution-Non Commercial Lisence (by-nc) Spain 3.0. 


\section{INTRODUCTION}

In the $19^{\text {th }}$ century the ctenostome bryozoan Zoobotryon verticillatum (Delle Chiaje, 1822) was often misidentified as a macroalga and was reported under different names (Ulva intricata Clemente, Valonia intricata Agardh, Ascothamnion intricatum Kützing, Ascothamnion trinitatis Sonder) from different world regions: Cadiz (Spain, near the Gibraltar Strait, the first known record for this species; De Roxas Clemente 1807), Malaga and Algiers (Mediterranean Sea), the Red Sea, the Antilles and Trinidad (Atlantic Ocean), Mauritius (Indian Ocean) and Mariana Island (Pacific Ocean; Agardh 1823, Kützing 1843, Durieu de Maisonneuve 1848, Zanardini 1858, Reichert 1870). The first descriptions as an animal species occurred in Naples, Italy under the name Hydra verticillata Delle Chiaje 1822, and later in Alexandria (Egypt, Mediterranean Sea) and the Red Sea under the name Zoobotryon pellucidus Ehrenberg, 1829. After a recent nomenclatural revision of ctenostome bryozoans (Waeschenbach et al. 2015), the genus Zoobotryon was concluded to be a junior subjective synonym of Amathia, and the name Z. verticillatum was changed to Amathia verticillata (Delle Chiaje, 1822) comb. n., which has now to be intended as its valid name.

It is because of those widespread early records that its occurrence within the Mediterranean has led to the presumption that this species is native to this region. It is currently known from tropical to subtropical localities in the Atlantic and Indo-Pacific region, and recently it has expanded its range within Macaronesia (Amat and Tempera 2009, Wirtz and Canning-Clode 2009, Minchin 2012). Such a cosmopolitan distribution has posed questions as to its real native origin: Winston (1995) suggested an origin from the Caribbean region, whilst Floerl et al. (2009a) labelled it as being cryptogenic and Vieira et al. (2014) suggested that, since a wide range of habitats are occupied, $A$. verticillata may contain cryptic species. In a recent account, Galil and Gevili (2014) suggested that it had properties and a history unlikely to have originated within the Mediterranean Sea because of its occurrence mainly on artificial habitats in harbours. It is now believed to be native to the Caribbean Sea, where it inhabits natural habitats such as sea-grass meadows, mangroves, oyster reefs and rocky shores and has apparently co-evolved with the goniodorid nudibranch Okenia zoobotryon (Smallwood, 1910), known to live, feed and reproduce exclusively on A. verticillata (Galil and Gevili 2014). This bryozoan subsequently became introduced elsewhere, including Macaronesia and the Mediterranean Sea (Wirtz and Canning-Clode 2009, Galil and Gevili 2014). Therefore, its status should now be considered to be pseudo-indigenous in the Mediterranean Sea (Ferrario et al. 2014), i.e. a non-indigenous species (NIS) having long been perceived to be native (Carlton 2009).

Amathia verticillata has been recorded mainly from enclosed habitats, such as coastal lagoons and embayments or their artificial equivalents, harbours and marinas. For example, in France A. verticillata was previous- ly recorded in Menton (Joliet 1888), Marseille Harbour (Gautier 1962) and Martigues Harbour (Chimenz et al. 1981). In particular, its stolons are capable of attaching to different substrates, including smooth surfaces, and it can develop colonies by a process of budding. Colonies vary greatly in shape and size, being either elongated and hanging up to $2 \mathrm{~m}$ in length (Minchin 2012) or shorter and bushy (Zirpolo 1933), and sometimes reaching a high biomass (Lenzi et al. 2009).

Due to its outstanding spreading capability, $A$. verticillata can have ecological and economic impacts (Gossett et al. 2004). It can form extensive fouling in harbours and marinas, on vessels and on fishing gear, and it has been known to clog the intake of abstraction pipework (Ryland 1965). Moreover, this effective suspension feeder can remove large volumes of planktonic material, affecting food web dynamics (Amat and Tempera 2009). It has also been listed on the Global Invasive Species database as an impacting species (www. issg.org, Accessed Jan 17, 2015). Specifically, this bryozoan species causes extensive fouling on Zostera spp. in summer, contributing to its decline (Williams 2007). In the Galveston Bay (Texas, USA), A. verticillata was listed as having the highest ecological risk score and least feasibility for control and/or eradication (Gosset et al. 2004). Although its soft colonies can be easily detached from hulls by mechanical removal, stolons are likely to persist and regenerate new colonies, whilst viable fragments dislodged during manual removal may survive and subsequently reattach once the environmental conditions become favourable (Hopkins and Forrest 2008).

This NIS should receive attention within the Mediterranean Sea as being a nuisance species, as has been suggested elsewhere (Coleman 1999, Farrapeira 2011, Minchin 2012, Nagy 2013). In particular, following the requirements of the European Marine Strategy Directive (EC 2008), its "trends in abundance, temporal occurrence and spatial distribution in the wild [...] notably in high risk areas, in relation to the main vectors and pathways of spreading" should be assessed (MSFD Descriptor 2, Criterion 2.1, Indicator 2.1.1; see also Ojaveer et al. 2014).

Unfortunately, due to its status of being a pseudoindigenous species, A. verticillata has so far received little attention from Mediterranean researchers. Here, we present an updated account on the currently known distribution of $A$. verticillata in the Mediterranean Sea and NE Atlantic region. We also apply a rapidassessment method to quantify the relative abundance of A. verticillata within La Grande Motte marina on the Mediterranean coast of France, a method which is easily replicable elsewhere. Furthermore, we describe some associated fauna new to the French coast associated with this bryozoan.

\section{MATERIALS AND METHODS}

La Grande Motte (Fig. 1) is a popular seaside resort and port, built in the 1960s-1970s in the region of Languedoc-Roussillon near the town of Montpellier (Southern France), located between the "Étang de 


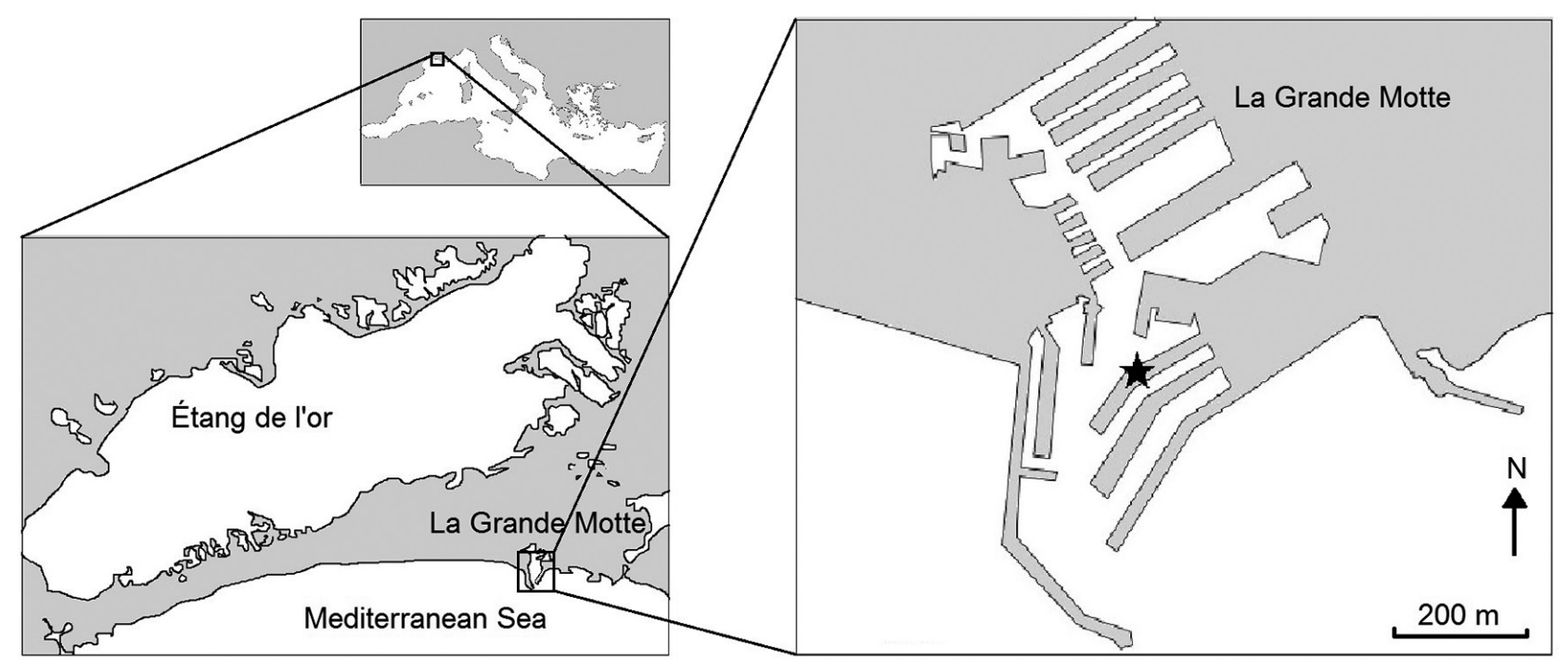

Fig. 1. - La Grande Motte marina on the Mediterranean coast of southern France. The pontoons that were sampled lie beneath the boardwalk indicated with a star.

l'or" lagoon and the Mediterranean Sea. It hosts a large marina providing 1374 berths. Many of the berthed recreational vessels have different registration ports ranging from the western Atlantic to the Indo-Pacific, and also including several regions within the Mediterranean Sea and Northern Europe.

The floating pontoons supporting a boardwalk in $\mathrm{La}$ Grande Motte marina (4333'19.16”N, 404'53.78”E; Fig. 1) were sampled on 19 November 2014 using a rapid sampling method which was undertaken within a two-hour period. A single boardwalk was examined near to the sea entrance of the marina which is protected by a breakwater. The floating units, pontoons, each approximately $1 \mathrm{~m}$ in length, supported a boardwalk of $220 \mathrm{~m}$ in overall length. A sample of 30 pontoons were examined at spaced distances along each open pontoon side.

The abundance and distribution range (ADR) used in this study was based on the method within the biopollution assessment method of Olenin et al. (2007), the method recommended for biological surveys elsewhere for port regions (Awad et al. 2014). The size of the assessment unit, used in this case, was a single boardwalk within the marina for the period November 2014. This assessment is based on the abundance and frequency of $A$. verticillata colonies occurring on each individual pontoon supporting a single boardwalk. Abundance was considered 'low' with fewer than ten colonies per pontoon, 'moderate' with 10-50 colonies per pontoon and 'high' with more than 50 colonies per pontoon. The distribution scales for each assessment unit ranged from 'local', if present on one pontoon, 'several localities' if present in fewer than half the pontoons examined, 'many localities' if present on more than half of the pontoons, and 'all localities' if present on all the pontoons. Combinations of abundance and distribution provide a scale that ranges from ' $\mathrm{A}$ ', few colonies present on one pontoon, to ' $\mathrm{E}$ ', high numbers on all pontoons (Table 1). From the abundance of colonies on pontoons, an estimate of the total numbers beneath the boardwalk was possible. Additional observations were also made on the narrow gap sections between pontoon units.

The presence/absence of colonies attached to the hulls of berthed leisure craft was based on what could be observed from the boardwalk on the forward or stern sections of the craft, according to how these were berthed. From this a prevalence of $A$. verticillata was obtained.

Some colonies were selected from the pontoons and other structures associated with the marina such as ladders, fenders and submerged ropes, for examination of the biota associated with $A$. verticillata colonies. Samples were preserved in 4\%-5\% solution of formaldehyde in seawater and further submitted to taxonomic identification.

The distribution of $A$. verticillata from different countries and sea sectors within the Mediterranean Sea basin and NE Atlantic, including Macaronesia, were obtained from the literature and personal observations and communications.

\section{RESULTS}

The immersed sides of the pontoons were extensively populated with colonies of $A$. verticillata (Fig. 2A) with a prevalence of $96 \%$ and an estimated inten-

Table 1. - Classes of abundance and distribution (ADR) according to Olenin et al. (2007). According to this scheme, Amathia verticillata should obtain level "C" (see text).

\begin{tabular}{lcccc}
\hline Abundance & & \multicolumn{2}{c}{ Distribution scale } & All localities \\
& One locality & Several localities & Many localities & C \\
Low & A & A & B & D \\
Medium & B & B & D & E \\
High & B & C & D & \\
\hline
\end{tabular}




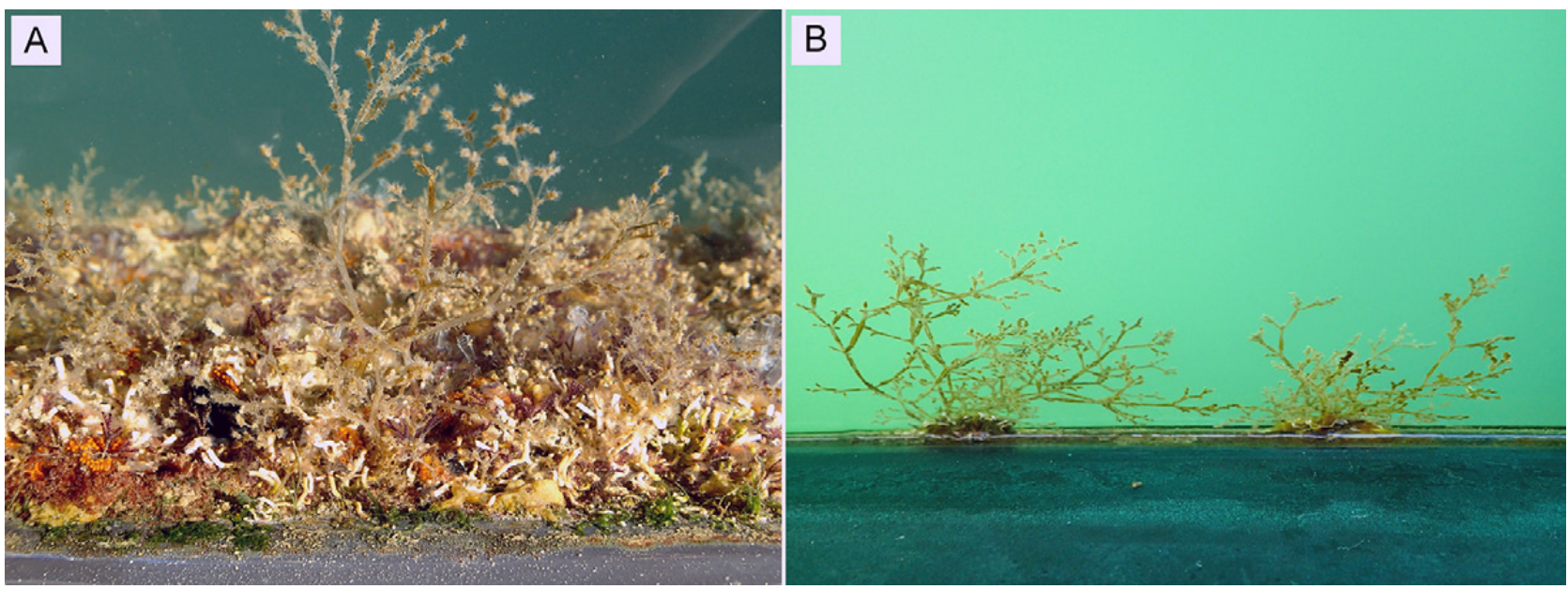

Fig. 2. - Colonies of Amathia verticillata attached to (A) a pontoon and (B) a leisure craft hull.

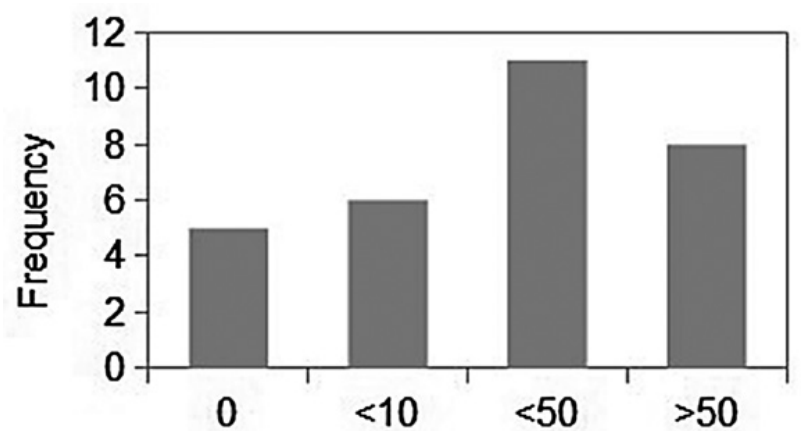

Fig. 3. - Colony number per pontoon examined.

sity of between $>10$ and $<50$ colonies per pontoon, providing an overall conservative estimate of colony numbers of $>10000$ beneath a single boardwalk (Fig. 3 ). Colonies on each pontoon ranged from none, for a short distance along a semi-exposed part of the boardwalk, to more than 50 colonies along a single pontoon side. Colonies were clearly recognized when they had attained a size of $2 \mathrm{~cm}$ or greater, and some extended to more than $20 \mathrm{~cm}$ in colony height at the time of the study. Colonies were present on more than half of the examined pontoons, which represented an occurrence at 'many localities', at a 'moderate' level
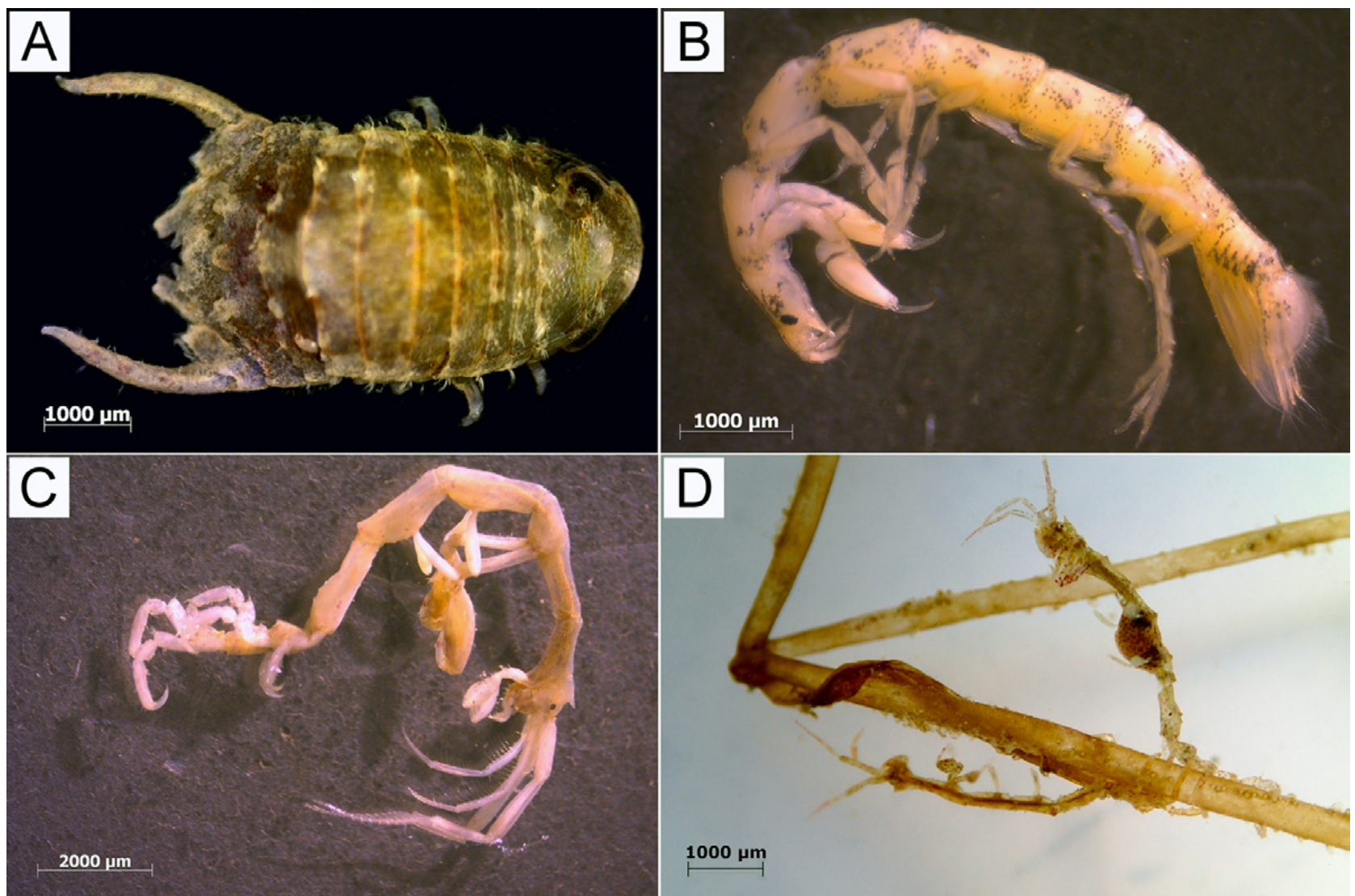

Fig. 4. - Non-indigenous peracarids associated with the spaghetti bryozoan in La Grande Motte: (A) Paracerceis sculpta; (B) Paranthura japonica; (C) Caprella scaura; (D) C. scaura specimens attached to Amathia verticillata branches. 


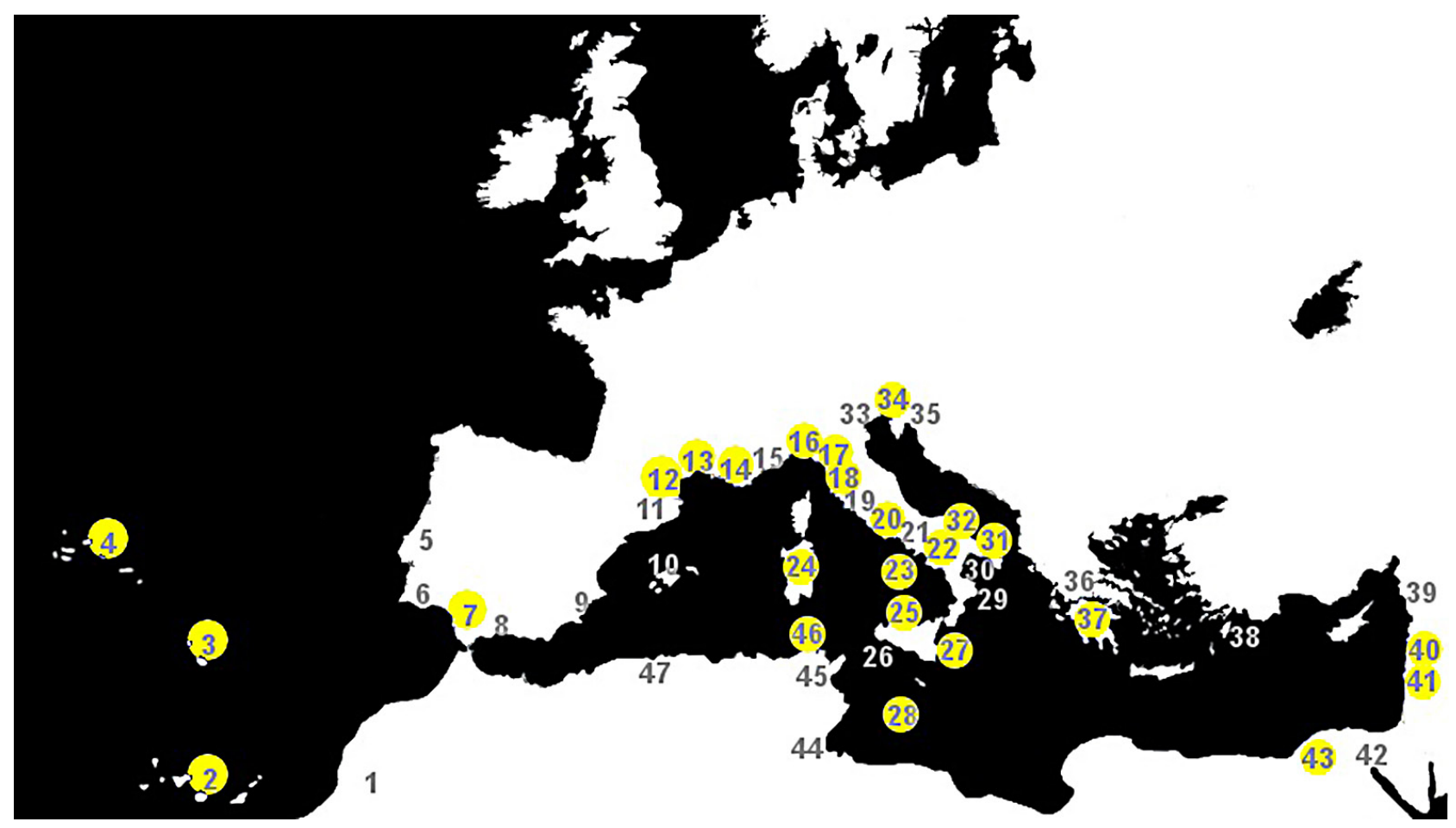

Fig. 5. - Known distribution of Amathia verticillata in the Mediterranean Sea and NE Atlantic. Records from harbours and marinas highlighted with circles. Numbers of records refer to Table 2.

of abundance to provide an ADR of ' $C$ '. A total of 114 berthed craft were visually examined and, of these, 35 were fouled with one or more A. verticillata colonies associated with their hulls to give a $31 \%$ prevalence. On many hulls the only fouling organism noted was A. verticillata (Fig. 2B), and on some boat hulls these were abundant. Although we did not perform estimates on the level of fouling on single boats, we could note from the boardwalk that fouling was greater on craft that did not appear to have been used recently and had "for sale" signs.

Colonies were attached to the sides, undersides and surfaces within the gaps between adjacent pontoons beneath the boardwalk; but were not present close to the surface water interface, where colonies of serpulids formed a distinctive horizon made up of Hydroides norvegicus Gunnerus, 1768, Spirobranchus lamarcki (Quatrefages, 1866), Janua sp. and the NIS Hydroides elegans (Haswell, 1883). Other prominent species of the fouling community included Bugula neritina (Linnaeus, 1758), Mytilus galloprovincialis Lamarck, 1819, and the cirripedes Amphibalanus amphitrite (Darwin, 1854) and the NIS Amphibalanus eburneus (Gould, 1841). The non-indigenous tunicate Styela plicata (Lesueur, 1823) was present on both pontoons and boat hulls. Elsewhere within the marina in the inner basin, other colonies of $A$. verticillata were present, suggesting that this bryozoan is extensively distributed throughout the marina.

Within the more sheltered conditions, diatomous films and sediment caused a dark green colouration on A. verticillata colonies, whereas in the more exposed conditions along the boardwalk these colonies were translucent. A. verticillata colonies sampled from both pontoons and boat hulls in the marina, especially those darker in colour, hosted a rich assemblage of small benthic species (polychaetes, nudibranchs, decapod and peracarid crustaceans, pycnogonids and ophiurids). Noteworthy was the presence of three nonindigenous peracarid species: the isopods Paracerceis sculpta (Holmes, 1904) (only one male specimen) and Paranthura japonica Richardson, 1909 (moderate abundance), and the caprellid amphipod Caprella scaura Templeton, 1836, which is the dominant species amongst the crustacean assemblage (Fig. 4 A-D).

Figure 5 shows the currently known distribution of A. verticillata in the Mediterranean Sea and NE Atlantic coasts, obtained from published and unpublished records. Most of these records were from the western Mediterranean (52\%). For 18 records (Table 2), there was no information on the habitat where A. verticillata was found. Excluding those, in $64 \%$ of the records A. verticillata was found on man-made substrates in harbours and marinas, in $9 \%$ in lagoons and in $27 \%$ in natural habitats.

With only a few exceptions, the available records of $A$. verticillata in the Mediterranean Sea are limited to presence data. Because data on its distribution and temporal occurrence are widely scattered over two centuries, quantitative data on its abundance are almost completely absent (Table 2 ).

\section{DISCUSSION}

In many aquatic environments throughout the world, the development of recreational berthing facilities has provided novel habitats for a wide range of species with a sessile life history stage and also for 


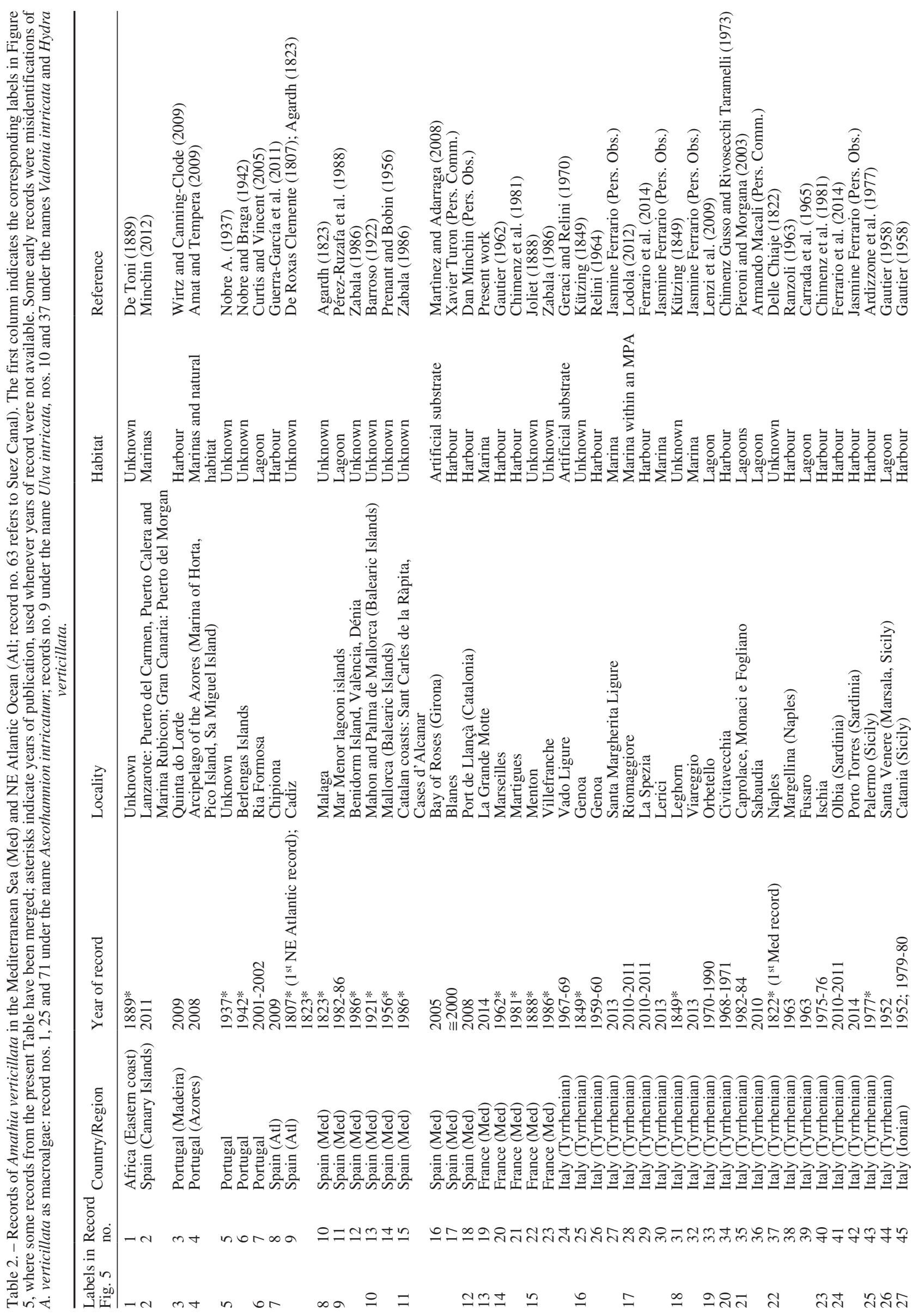



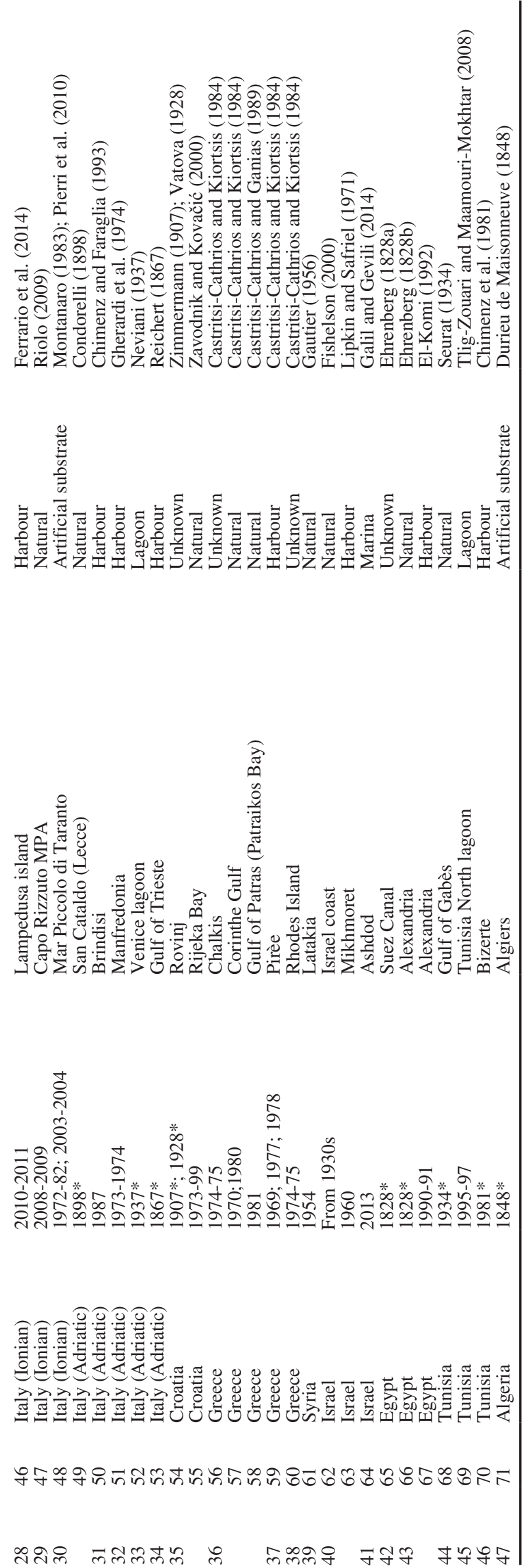

their associates (Clarke-Murray et al. 2014). These species may become distributed over a wide region, even across oceans (Minchin 2006). This may be the case of $A$. verticillata, which has biological traits that explain the success in its spread. In particular, its larvae and fragments can easily settle on a variety of natural and artificial substrates, including smooth and clean surfaces (Zirpolo 1933, Robinson 2004). Additionally, the basal stolon can resist low temperatures and strong currents (Zirpolo 1933), making this bryozoan well suited as a hull-fouling species. Moreover, A. verticillata produces active compounds (bromo-alkaloids), which probably provide protection by discouraging predation (e.g. Ortega et al. 1993).

The preponderance of records of $A$. verticillata from marinas worldwide (Ryland 1965, Ganapathi and Satyanarayana Rao 1968, Ardizzone and Riggio 1981, Gordon and Mawatari 1992, Hewitt et al. 2004, Ramadan et al. 2006, Abdel-Salam and Ramadan 2008, Carlton and Eldredge 2009, Wirtz and CanningClode 2009, Farrapeira 2011, Minchin 2012, Galil and Gevili 2014, Tamsouri et al. 2014) suggests that recreational craft may be involved in its spread. The arrival of A. verticillata to the NE Atlantic and Mediterranean Sea from the Caribbean region can only have been as ship hull fouling, as ballast water transmissions will not have taken place until more than 50 years after the time it was first described as an alga in Cadiz (Spain) and later as an animal in Naples (Italy). Even in modern times, the likelihood of transport by ballast water is low, since $A$. verticillata larvae remain only a few hours in the plankton (Zirpolo 1933). A. verticillata produces vegetative fragments from a colony that can survive and attach to new substrates (Robinson 2004). Although we cannot rule out the possibility that drifting fragments could survive in ballast waters, the transport of stolons, or full colonies, attached on vessel hulls provides a convincing hypothesis. Other transport mechanisms such as rafting on flotsam and drifting algae (Watts et al. 1998, Barnes 2002) may also increase the geographic range of bryozoan species. No such rafting was noted in the area of study.

The rapid-assessment method involving two workers was, within a two-hour period, sufficient to locate at least 7 NIS and undertake an ADR of A. verticillata in such a way that any significant change in abundance is likely to be measured during a re-visit. For a species such as this bryozoan, the method may even be suitable for measuring seasonal changes, especially if there is a winter decline. The ADR approach for a conspicuous species is effective when used on marinas, provided the same scoring system is used.

The occurrence of luxuriant colonies in November is noteworthy. Colonies are reported as occurring only during summer months in the Mediterranean Sea (Relini 1966, Galil and Gevili 2014), and they enter a senescent phase during the autumn (Zirpolo 1933). Along sheltered coasts $A$. verticillata has the ability to form overwintering stages from which new colonies can evolve (Geiger and Zimmer 2002) when temperatures become favourable. Therefore, an enclosed environment such as a Mediterranean marina could act as 
a suitable habitat during the winter. A eurytopic and euryecious species such as A. verticillata (Vieira et al. 2014) can endure the conditions within a marina on the south coast of France, where winter temperatures may descend to $11^{\circ} \mathrm{C}-14^{\circ} \mathrm{C}$ (http://www.surf-forecast.com/ breaks/La-Grande-Motte/seatemp, accessed Jan 17, 2015).

A conservative estimate of the number of colonies of A. verticillata at La Grande Motte marina exceeded 10000 colonies. Colonies less than $2 \mathrm{~cm}$ in height were not easily distinguished along the pontoon sides, so the overall numbers of colonies are likely to have been greater than estimated. In addition, colonies that were abundant within the small gaps between adjacent pontoons and those attached to boat hulls and other structures were not scored. Overall, within this marina featuring ten boardwalks (Fig. 1) the numbers might have exceeded 100000 colonies. Such a sheltered environment provides suitable summer temperatures for reproduction and growth, suitable salinities and organic enrichment. Indeed, marinas provide extensive surfaces for sessile biota many times greater than would otherwise occur naturally (Minchin et al. 2006). Moreover, the small tidal range in the Mediterranean involves a high retention of water, which makes the contention of propagules likely and explains the abundance on many different structures. Since the pelagic phase of the larvae is of the order of hours, retention of settling individuals is high (Zirpolo 1933). Clearly, the abundance of the colonies of A. verticillata in La Grande Motte marina is sufficient to provide enough propagules to infest boat hulls. Recruitment onto boat hulls is extensive: some had little macrobiofouling, whereas others had a greater diversity of biofouling taxa. The numerous large colonies observed in La Grande Motte might also generate drifting fragments that could become established in surrounding natural habitats. The occurrence of the species on natural substrata has been observed in the Azores (Amat and Tempera 2009), Italy (Riolo 2009) and Israel (Lipkin and Safriel 1971).

As reported by other authors (Farrapeira 2011, Ferrario et al. 2014) and in this study, A. verticillata has a varied associated fauna, mainly other bryozoans, nudibranchs, amphipods and isopods. Their presence indicates that $A$. verticillata may act as a special niche for smaller NIS, thereby enhancing opportunities for their spread on vessel hulls. In this study $A$. verticillata acted as a substrate for three non-indigenous crustaceans, representing the first records from the Mediterranean coast of France: Paracerceis sculpta, Paranthura japonica and Caprella scaura.

The NE Pacific isopod Paracerceis sculpta was first reported from Tunisia in 1978, and subsequently from Italy, Spain (Gibraltar Strait) and Greece (Fryganiotis and Chintoroglou 2014). Its occurrence in areas of shellfish farming as well as marinas indicate that it is polyvectic.

The NW Pacific isopod Paranthura japonica is again a likely pseudo-indigenous species, most probably introduced since the 1970s with shellfish transfers, but it has not previously been perceived to be an NIS as a result of earlier misidentifications (Marchini et al. 2014). It has been reported from the French Atlantic coast (Lavesque et al. 2013), and the Italian Adriatic and Tyrrhenian coasts (Marchini et al. 2014). The current record indicates that this NIS, previously thought to be associated with aquaculture, might also be spread as hull fouling on leisure craft.

The Indo-Pacific amphipod Caprella scaura is one of the most widespread NIS in European marine waters (Galil et al. 2014). It was first reported from the Lagoon of Venice (Italy) in 1994, and then spread rapidly, being able to colonize lagoons, harbours and marinas in the Mediterranean Sea to include Macaronesia (Minchin 2012, Ramalhosa et al. 2015). Recent molecular evidence suggests that its spread will have involved multiple introduction events of several sub-species (Cabezas et al. 2014). The present record of $C$. scaura in La Grande Motte represents the first record for continental France: the species was previously reported from the French island of Corsica (Ros et al. 2014).

The records from La Grande Motte (Fig. 3D), together with observations from the Mediterranean Sea and elsewhere, may have enabled the rapid spread of C. scaura, which has also been found firmly attached by means of its pereiopods to A. verticillata in other marinas in the Ligurian Sea (Jasmine Ferrario, personal observations), near Gibraltar (Guerra-García et al. 2011), on the Balearic Islands (Ros et al. 2013), on the Canary islands (Minchin 2012), on Madeira Island (Ramalhosa et al. 2015), and in Hilary Marina, Australia (Dan Minchin, personal observation). The spaghetti bryozoan has also been shown to be a host for nonindigenous nudibranchs such as Polycera hedgpethi Er. Marcus, 1964 (in Sicily, Italy: Giacobbe and De Matteo 2013); Polycerella emertoni A. E. Verrill, 1880 (in Agadir, Tunisia: Tamsouri et al. 2014); and Okenia spp. (Rudman 2004, Carlton and Eldredge 2009, Ortea et al. 2009).

\section{CONCLUSION}

It is very likely that marinas act as hubs for the dispersal of $A$. verticillata and its associates, particularly peracarids crustaceans and nudibranchs (O'Kelly and Miller 1994, Carlton 1996, Floerl et al. 2009b). The marina at La Grande Motte has a large number of berths with many visiting craft that have the capability of spreading these species to areas where they currently do not exist. This marina is recognized as serving many routes within the western Mediterranean Sea and with the continued development of marinas around the Mediterranean Sea (Cornell 2002, Savini et al. 2006) these species are likely to continue to expand. Because this NIS is able to regenerate from stolons as well as viable fragments, careful and conscientious hull maintenance routines are required. On account of the ability of $A$. verticillata to spread from fragments in water, hull-cleaning should be avoided. For this reason the boating industry must be made aware that there are NIS together with their associates, which require careful management to prevent their further spread. 


\section{ACKNOWLEDGEMENTS}

This work was supported by the European Union's Seventh Framework Programme for research, technological development and demonstration (FP7/20072013) within the Ocean of Tomorrow call under Grant Agreement No. 266445 for the project Vectors of Change in Oceans and Seas Marine Life, Impact on Economic Sectors (VECTORS); Jasmine Ferrario was supported by a $\mathrm{PhD}$ grant from the University of Pavia. The authors gratefully thank Armando Macali, Stefano Piraino and Xavier Turon for providing unpublished data and grey literature on A. verticillata distribution, and Anna Occhipinti for commenting on an earlier draft. We also thank two reviewers for their useful comments and literature suggestions.

\section{REFERENCES}

Abdel-Salam K.H.M., Ramadan S.H.E. 2008. Fouling bryozoa from some Alexandria harbours, Egypt. (I) erect species. Mediterr. Mar. Sci. 9(2): 5-20.

http://dx.doi.org/10.12681/mms.129

Agardh C.A. 1823. Species algarum rite cognitae, cum synonymis, differentiis specificis et descriptionibus succinctis. Volumen primum pars posterior. pp. [vii-viii], [399]-531. Lundae [Lund]: ex officina Berlingiana.

Amat J.N., Tempera F. 2009. Zoobotryon verticillatum Delle Chiaje, 1822 (Bryozoa), a new occurrence in the archipelago of the Azores (North-Eastern Atlantic). Mar. Pollut. Bull. 58(5): 761-764.

http://dx.doi.org/10.1016/j.marpolbul.2009.02.019

Ardizzone G., Riggio S. 1981. Similitudine e diversitá nelle biocenosi bentoniche del Porto di Palermo in relazione al substrato di insediamento. Quad. Lab. tecnol. pesca 3(1): 587-603.

Ardizzone G.D., Mazzola A., Riggio S. 1977. Modificazioni nelle comunità incrostanti del porto di Palermo in relazione a diverse condizioni ambientali. Atti IX Congresso SIBM, pp. 151-159.

Awad A., Haag F., Anil A.C., et al. 2014. Guidance on port biological baseline surveys. GEF-UNDP-IMO GloBallast Partnerships, London, UK. GloBallast Monograph 22: 48 pp.

Barnes D.K.A. 2002. Invasions by marine life on plastic debris. Nature 416: 808-809. http://dx.doi.org/10.1038/416808a

Barroso M.G. 1922. Notas sobre briozoos marinos españoles. X. Especiés de Mahon, Baleares. Bol. R. Soc. Esp. Hist. Natur. Madrid 22: 88-101.

Cabezas M.P., Xavier R., Branco M., et al. 2014. Invasion history of Caprella scaura Templeton, 1836 (Amphipoda: Caprellidae) in the Iberian Peninsula: multiple introductions revealed by mitochondrial sequence data. Biol. Invasions 16(10): 1-25. http://dx.doi.org/10.1007/s10530-014-0660-y

Carlton J.T. 1996. Pattern, process, and prediction in marine invasion ecology. Biol. Conserv. 78: 97-106. http://dx.doi.org/10.1016/0006-3207(96)00020-1

Carlton J.T. 2009. Deep invasion ecology and the assembly of communities in historical time. In: Rilov G., Crooks J.A. (eds), Biological Invasions in Marine Ecosystems. Ecological Studies 204, Springer-Verlag Berlin Heidelberg, pp. 13-56. http://dx.doi.org/10.1007/978-3-540-79236-9_2

Carlton J.T., Eldredge L.G. 2009. The introduced and cryptogenic marine and estuarine animals and plants of the Hawaiian Archipelago. Bishop Mus. Bull. Cultur. Environ. Stud. 4: 1-203.

Carrada G.C., Sacchi C.F., Rigillo M.T. 1965. Ricerche sulla valenza ecologica dei briozoi salmastri. I - Significato delle variazioni ritmiche dei fattori ambientali. Boll. Pesca Piscic. Idrobiol. 20(2): 153-208.

Castritsi-Catharios J., Kiortsis V. 1984. Bryozoaires côtiers de Grèce. Proposition d'une méthode automatisée de détermination systématique. Biol. Gallo-Hell., 11(1): 89-98.

Castritsi-Catharios J., Ganias G. 1989. Bryozoaires épiphytes de l'herbier de Posidonies du Golfe de Patras (Greece). II International Workshop on Posidonia Beds 2: 157-160.

Chimenz C., Faraglia E. 1993. Contributo allo studio dei briozoi pugliesi. Biol. Mar. Mediterr. Supplemento al Notiziario
S.I.B.M. 1: 293.

Chimenz C., Fresi E., Cinelli F., et al. 1981. Ricerche sui popolamenti bentonici di substrato dure del porto d'Ischia. Briozoi. Mem. Biol. Mar. Oceanogr. 6 (4): 187-206.

Chimenz Gusso C., Rivosecchi Taramelli E. 1973. Osservazioni sulle biocenosi incrostanti piastre di eternit immerse a diversa profondità nel porto di Civitavecchia. Boll. Pesca Piscic. Idrobiol. 28(1): 77-100

Clarke-Murray C., Gartner H., Gregr E.J., et al. 2014. Spatial distribution of marine invasive species: environmental, demographic and vector drivers. Divers. Distrib. 20: 824-836. http://dx.doi.org/10.1111/ddi.12215

Coleman F.S. 1999. Note on Zoobotryon verticillatum (Bryozoa) in a solar saltfield. Int. J. Salt Lake Res. 8(1): 71-74. http://dx.doi.org/10.1023/A:1009088401641

Condorelli M. 1898. Invertebrati raccolti dalla R. Nave "Scilla" nell' Adriatico e nel Jonio. Boll. Soc. Studi Zool. Roma, 7: 25-49.

Cornell J. 2002. World Cruising Routes. International Marine, McGraw Hill, London, 624 pp.

Curtis J.M.R., Vincent A.C.J. 2005. Distribution of sympatric seahorse species along a gradient of habitat complexity in a seagrass-dominated community. Mar. Ecol. Prog. Ser. 291: 81-91. http://dx.doi.org/10.3354/meps291081

Delle Chiaje S. 1822. Memorie sulla storia e notomia degli animali senza vertebre del Regno di Napoli. Vol. 1. dalla stamperia de 'Fratelli Fernandes'. http://dx.doi.org/10.5962/bhl.title.46298

De Toni G.B. 1889. Sylloge algarum omnium hucusque cognitarum. Vol. I. Sylloge chlorophycearum omnium hucusque cognitarum, $12 \mathrm{pp}$. http://dx.doi.org/10.5962/bhl.title.10544

De Roxas Clemente R.S. 1807. Ensayo sobre las variedades de la vid comun que vegetan en Andalucía, con un índice etimológico y tres listas de plantas en que se caracterizan varias especies nuevas, por Don Simon de Roxas Clemente y Rubio. pp. [i]xviii + [1]-324, 1 pl. Madrid (Imp. de Villalpando).

Durieu de Maisonneuve M.C. 1848. Exploration scientifique de l'Algérie. Botany 1(10): 361-400.

EC [European Commission] 2008. Directive 2008/56/EC of the European Parliament and of the Council of 17 June 2008 establishing a framework for community action in the field of marine environmental policy (Marine Strategy Framework Directive). Official Journal of the European Union L 164: 19-40.

Ehrenberg C.G. 1828a. Symbolae physicae animalia evertebrata exclusis insectis. Symbolae physicae, seu Incones adhue ineditae corporum naturalium novorum aut minus cognitorum, quae ex itinerebus per Libyam, Aegyptum, Nubiam, Dengalum, Syriam, Arabiam et Habessiniam. Pars Zoologica, 4.

Ehrenberg C.G. 1828b. Die geographische Verbreitung der Infusionsthierchen in Nord-Afrika und West-Asien: beobachtet auf Hemprich und Ehrenbergs Reisen, 20 pp.

El-Komi M.M. 1992. Field and laboratory studies on the ecology of marine fouling in Alexandria harbour, Egypt. Bull. Nat. Inst. Oceanogr. Fish. A.R.E. 18: 115-140.

Farrapeira C.M.R. 2011. The introduction of the bryozoan Zoobotryon verticillatum (Delle Chiaje, 1822) in northeast of Brazil: a cause for concern. Biol. Invasions 13(1): 13-16. http://dx.doi.org/10.1007/s10530-010-9788-6

Ferrario J., Marchini A., Lodola A., et al. 2014. The pseudoindigenous bryozoan Zoobotryon verticillatum along the Mediterranean and Atlantic European coasts. Biol. Mar. Mediterr. 21(1): 117-118.

Fishelson L. 2000. Marine animal assemblages along the littoral of the Israeli Mediterranean seashore: the Red-Mediterranean Seas communities of species. Ital. J. Zool. 67(4): 393-415. http://dx.doi.org/10.1080/11250000009356345

Floerl O., Inglis G.J., Gordon D.P. 2009a. Patterns of taxonomic diversity and relatedness among native and non-indigenous bryozoans. Divers. Distrib. 15: 438-449. http://dx.doi.org/10.1111/j.1472-4642.2008.00553.x

Floerl O., Inglis G.J., Dey K., et al. 2009b. The importance of transport hubs in stepping-stone invasions. J. Appl. Ecol. 46(1): 37-45. http://dx.doi.org/10.1111/j.1365-2664.2008.01540.x

Fryganiotis K., Chintoroglou Ch. 2014. First record of the isopod Paracerceis sculpta in the Aegean Sea: established populations in north Aegean marinas. In: Katsanevakis S., Acar Ü., Ammar I., et al., New Mediterranean Biodiversity Records (October, 2014). Mediterr. Mar. Sci. 15: 667-687.

Galil B.S., Gevili R. 2014. Zoobotryon verticillatum (Bryozoa: Ctenostomatida: Vesiculariidae), a new occurrence on the 
Mediterranean coast of Israel. Mar. Biodivers. Rec. 7: e17. http://dx.doi.org/10.1017/S1755267214000086

Galil B.S., Marchini A., Occhipinti-Ambrogi A., et al. 2014. International arrivals: widespread bioinvasions in European Seas. Ethol. Ecol. Evol. 26: 152-171.

http://dx.doi.org/10.1080/03949370.2014.897651

Ganapathi P.N., Satyanarayana Rao K. 1968. Fouling bryozoans in Visakhapatnam Harbour. Curr. Sci. 37: 81-89.

Gautier Y.V. 1956. Première faunule des bryozoaires des cotes syriennes. Vie Milieu 7(4): 554-561.

Gautier Y.V. 1958. Bryozoaires marins actuels de Sicile. Att. Soc. Pelorit. Sci. Fis. Math. Nat. 4(2): 45-68.

Gautier Y.V. 1962. Recherches écologiques sur les Bryozoaires Chilostomes en Méditerranée Occidentale. Re. Trav. St. Mar. Endoume 38(24): 1-434.

Geiger D.L., Zimmer R.L. 2002. Anchoring rootlets in Bowerbankia imbricata (Bryozoa: Ctenostomata). Bull. Mar. Sci. 70 (3): 791-797.

Geraci S., Relini G. 1970. Insediamento su pannelli atossici immersi nella Rada di Vado Ligure: i Briozoi. Pubbl. Sta. Zool. Napoli 38: 19-33

Gherardi M., Lepore E., Muscio A., et al. 1974. Study on Manfredonia harbour's fouling communities. Mem. Biol. Mar. Oceanogr. 4, 5, 6: 275-287.

Giacobbe S., De Matteo S. 2013. The potentially invasive opisthobranch Polycera hedgpethi Er. Marcus, 1964 (Gastropoda Nudibranchia), introduced in a Mediterranean coastal lagoon. Biodiv. J. 4(2): 359-364.

Gordon D.P., Mawatari S.F. 1992. Atlas of marine-fouling Bryozoa of New Zealand ports and harbours. Misc. Publ. N. Z. Oceanogr. Inst. 107: 1-52.

Gosset L., Lester J., Gonzales L. 2004. Galveston Bay Invasive Species Risk Assessment - Final Report. Galveston Bay Estuary Program, Texas Commission on Environmental Quality, Texas, 57 pp.

Guerra-García J.M., Ros M., Dugo-Cota A., et al. 2011. Geographical expansion of the invader Caprella scaura (Crustacea: Amphipoda: Caprellidae) to the East Atlantic coast. Mar. Biol. 158(11): 2617-2622. http://dx.doi.org/10.1007/s00227-011-1754-z

Hewitt C.L., Campbell M.L., Thresher R.E., et al. 2004. Introduced and cryptogenic species in Port Phillip Bay, Victoria, Australia. Mar. Biol. 144(1): 183-202. http://dx.doi.org/10.1007/s00227-003-1173-x

Hopkins G.A., Forrest B.M. 2008. Management options for vessel hull fouling: an overview of risks posed by in-water cleaning. ICES J. Marine Sci. 65(5): 811-815. http://dx.doi.org/10.1093/icesjms/fsn026

Joliet L. 1888. Bryozoaries nouveaux de Roscoff et Bryozoaries de Menton. Arch. Zool. Exp. Gén. 2(6): 103-109.

Kützing F.T. 1843. Phycologia generalis oder Anatomie, Physiologie und Systemkunde der Tange. F.A. Brockhaus, Leipzig.

Kützing F.T. 1849. Species algarum. F.A. Brockhaus, Leipzig, 922 pp.

Lavesque N., Sorbe J.-C., Bachelet G., et al. 2013. Recent discovery of Paranthura japonica Richardson, 1909 (Crustacea: Isopoda: Paranthuridae) in European marine waters (Arcachon Bay, Bay of Biscay). BioInvasion Rec. 2(3): 215-219. http://dx.doi.org/10.3391/bir.2013.2.3.07

Lenzi M., Birardi F., Boddi S., et al. 2009. The lagoon of Orbetello. In: Cecere E., Petrocelli A., Izzo G. (eds), Flora and Vegetation of the Italian Transitional Water Systems. Lagunet, CORILA, Venice, pp. 111-123

Lipkin Y., Safriel U. 1971. Intertidal zonation on rocky shores at Mikhmoret (Mediterranean, Israel). J. Ecol. 59: 1-30. http://dx.doi.org/10.2307/2258448

Lodola A. 2012. Xenodiversity in Marine Protected Areas: three case studies in Italy. PhD Thesis, Univ. Pavia, Italy, 249 pp.

Marchini A., Sorbe J.-C., Torelli F., et al. 2014. The non-indigenous Paranthura japonica Richardson, 1909 in the Mediterranean Sea: travelling with shellfish? Mediterr. Mar. Sci. 15(3): 545-553.

Martìnez J., Adarraga I. 2008. First record of invasive caprellid Caprella scaura Templeton, 1836 sensu lato (Crustacea: Amphipoda: Caprellidae) from the Iberian Peninsula. Aq. Inv. 3(2): 165-171. http://dx.doi.org/10.3391/ai.2008.3.2.6

Minchin D. 2006. The transport and the spread of living aquatic species. In: Davenport J., Davenport J.L. (eds), The ecology of transportation: managing mobility for the environment. Springer, Berlin Heidelberg New York, pp. 77-97. http://dx.doi.org/10.1007/1-4020-4504-2 5

Minchin D. 2012. Rapid assessment of the bryozoan, Zoobotryon verticillatum (Delle Chiaje, 1822) in marinas, Canary Islands.
Mar. Pollut. Bull. 64(10): 2146-2150 http://dx.doi.org/10.1016/j.marpolbul.2012.07.041

Montanaro C. 1983. Settlement of bryozoans in the Mar Piccolo of Taranto (Southern Italy) from 1972 to 1982 . Oebalia 9: 91-103.

Nagy L. 2013. Early detection and rapid response. Managers Tool Kit. (Accessed Jan 26, 2015) http://www.invasivespeciesinfo.gov/toolkit/detelk.shtml

Neviani A. 1937. I briozoi della laguna veneta. Boll. Pesca Piscic. Idrobiol. 13: 382-403.

Nobre A. 1937. Fauna Marinha de Portugal. 1 aditamento. Mem. Mus. Zool. Univ. Coimbra 93: 1-30.

Nobre A., Braga S.M. 1942. Notas sôbre a Fauna das Ilhas Berlengas e Farilhôes. Mem. Mus. Zool. Univ. Coimbra 138: 1-66.

O'Kelly M.E., Miller H.J. 1994. The hub network design problem: a review and synthesis. J. Transp. Geogr. 2: 31-40. http://dx.doi.org/10.1016/0966-6923(94)90032-9

Ojaveer H., Galil B.S., Minchin D., et al. 2014. Ten recommendations for advancing the assessment and management of non-indigenous species in marine ecosystems. Mar. Policy 44: $160-165$. http://dx.doi.org/10.1016/j.marpol.2013.08.019

Olenin S., Minchin D., Daunys D. 2007. Assessment of biopollution in aquatic ecosystems. Mar. Pollut. Bull. 55(7): 379-394. http://dx.doi.org/10.1016/j.marpolbul.2007.01.010

Ortea J., Moro L., Espinosa J. 2009. El género Okenia Menke, 1830 (Mollusca: Nudibranchia) en las islas Canarias con notas sobre Okenia zoobotryon (Smallwood, 1910), una especie en controversia permanente. Vieraea 37: 75-83.

Ortega M.J., Zubia E., Salva J. 1993. A new brominated indole3 -carbaldehyde from the marine bryozoan Zoobotryon verticillatum. J. Nat. Prod. 56(4): 633-636. http://dx.doi.org/10.1021/np50094a031

Pérez-Ruzafa À., Pérez-Ruzafa I.M., Marcos C., et al. 1988. Cartografia bionómica del poblamiento bentónico de las islas del Mar Menor. Islas Perctiguera y del Barón. Oecol. Aquat. 9: 27-40.

Pieroni A., Morgana J.G. 2003. Progetto "Parchi in Qualità", ovvero "applicazione pilota del Sistema di Gestione Ambientale nella aree naturali protette". La Fauna del Parco Nazionale del Circeo. ENEA, Casaccia, $81 \mathrm{pp}$.

Pierri C., Longo C., Giangrande A. 2010. Variability of fouling communities in the Mar Piccolo of Taranto (Northern Ionian Sea, Mediterranean Sea). J. Mar. Biol. Ass. U. K. 90: 159-167. http://dx.doi.org/10.1017/S0025315409990798

Prenant M., Bobin G. 1956. Bryozoaires. Premiere parte. Entoproctes, Phylactolèmes, Cténostomes. Faune de France, 60: 389 pp.

Ramadan S.E., Kheirallah A.M., Abdel-Salam K.M. 2006. Marine fouling community in the Eastern harbour of Alexandria, Egypt compared with four decades of previous studies. Mediterr. Mar. Sci. 7(2): 19-30. http://dx.doi.org/10.12681/mms.167

Ramalhosa P., Canning-Clode J. 2015. The invasive caprellid $\mathrm{Ca}$ prella scaura Templeton, 1836 (Crustacea: Amphipoda: Caprellidae) arrives on Madeira Island, Portugal. BioInvasion Rec. 4(2): $97-102$. http://dx.doi.org/10.3391/bir.2015.4.2.05

Ranzoli F. 1963. Studio quantitativo della sessualità in colonie di Zoobothryon verticillatum (Delle Chiaje). Arch. Zool. Ital. 48: 227-253.

Reichert K.B. 1867. Über die contractile substanz (Sarcode, protoplasma) und ihre Bewegungserscheinungen bei Polythalamien und einigen anderen niederen thieren. Abhandlungen der königlichen Akademie der Wissenschaften zu Berlin, F. Dümmler, Berlin, 145 pp.

Reichert K.B. 1870. Vergleichende anatomische untersuchungen über Zoobotryon pellucidus (Ehrenberg). Buchdruckerei der königlichen Akademie der Wissenschaften zu Berlin, F. Dümmler, Berlin, 338 pp. http://dx.doi.org/10.5962/bhl.title.11342

Relini G. 1964. Andamento stagionale degli organismi sessili del Porto di Genova. Archo. Oceanogr. Limnol. 13(2): 281-296.

Relini G. 1966. Le comunità dominanti nel 'fouling' portuale di Genova. Natura 57: 136-156.

Riolo F. 2009. Valutazione e monitoraggio della presenza e stato di salute dei coralli madreporari (scleractinia) nell'Area Marina Protetta Capo Rizzuto (anno 2009). Technical report, Capo Rizzuto MPA, Italy, $19 \mathrm{pp}$. Available at:

http://www riservamarinacaporizzuto.it/dati/upload/files/ RELAZIONE_MONITORAGGIO_CORALLI\%281\%29.pdf.

Robinson N.M. 2004. Interactions between the nudibranch Okenia zoobotryon and its bryozoan prey Zoobotryon verticillatum. 
Thesis, Master of Sciences. Univ. Central Florida, Orlando, Florida, $67 \mathrm{pp}$.

Ros M., Vázquez-Luis M., Guerra-García J.M. 2013. The tropical caprellid amphipod Paracaprella pusilla a new alien crustacean in the Mediterranean Sea. Helgoland Mar. Res. 67(4): 675-685. http://dx.doi.org/10.1007/s10152-013-0353-4

Ros M., Guerra-García J.M., Navarro-Barranco C., et al. 2014. The spreading of the non-native caprellid (Crustacea: Amphipoda) Caprella scaura Templeton, 1836 into southern Europe and northern Africa: a complicated taxonomic history. Mediterr. Mar. Sci. 15: 145-155.

Rudman W.B. 2004. Further species of the opisthobranch genus Okenia (Nudibranchia: Goniodorididae) from the Indo-West Pacific. Zootaxa 695: 1-70.

Ryland J.S. 1965. Catalogue of main fouling organisms (found on ships coming into European waters). Volume 2: Polyzoa. OECD, $84 \mathrm{pp}$.

Savini D., Occhipinti-Ambrogi A., Minchin D., et al. 2006. A concealed aspect in coastal water conservation: the diffusion of alien species by recreational craft. Biol. Mar. Mediterr. 13(1): 764-772.

Seurat L.G. 1934. Formations littorales et estuaires de la Syrte Mineure (Golfe de Gabès). Bull. Stn. Océanogr. Salammbô 32: $1-65$

Tamsouri N., Carmona L., Moukrim A., et al. 2014. Polycerella emertoni and Favorinus ghanensis: two new alien sea slug molluscs from the Moroccan Atlantic coasts. Mar. Biodivers. Rec. 7: e13. http://dx.doi.org/10.1017/S1755267214000050

Tlig-Zouari S., Maamouri-Mokhtar F. 2008. Macrozoobenthic species composition and distribution in the Northern lagoon of Tunis. Transit. Water. Bull. 2: 1-15.

Vatova A. 1928. Compendio della Flora e della Fauna del. Mare Adriatico presso Rovigno. Mem. R. Com. Talassogr. Ital. 143: 1-614.
Vieira L.M., Migotto A.E., Winston J.E. 2014. Ctenostomatous Bryozoa from São Paulo, Brazil, with descriptions of twelve new species. Zootaxa 3889(4): 485-524. http://dx.doi.org/10.11646/zootaxa.3889.4.2

Waeschenbach A. Vieira L.M., Reverter-Gil O, et al. 2015. A phylogeny of Vesiculariidae (Bryozoa, Ctenostomata) supports synonymisation of three genera and reveals possible cryptic diversity. Zool. Scripta, in press. http://dx.doi.org/10.1111/zsc.12130

Watts P.C., Thorpe J.P., Taylor P.D. 1998. Natural and anthropogenic dispersal mechanisms in the marine environment: a study using cheilostome Bryozoa. Philos. Trans. R. Soc. Lond. B. 353: 453-464. http://dx.doi.org/10.1098/rstb.1998.0222

Williams S.L. 2007. Introduced species in seagrass ecosystems: status and concerns. J. Exp. Mar. Biol. Ecol. 350(1): 89-110. http://dx.doi.org/10.1016/j.jembe.2007.05.032

Winston J.E. 1995. Ectoproct diversity of the Indian River coastal lagoon. Bull. Mar. Sci. 57: 84-89.

Wirtz P., Canning-Clode J. 2009. The invasive bryozoan Zoobotryon verticillatum has arrived at Madeira Island. Aq. Inv. 4: 669-670. http://dx.doi.org/10.3391/ai.2009.4.4.11

Zabala M. 1986. Fauna dels briozous dels Països Catalans. Institut d'Estudis Catalans, Barcelona, $829 \mathrm{pp}$.

Zanardini G. 1858. Plantarum in mari rubro hucusque collectarum. Reale Istituto veneto, Venezia, $309 \mathrm{pp}$.

Zavodnik D., Kovačić M. 2000. Index of marine fauna in Rijeka bay (Adriatic Sea, Croatia). Nat. Croat. 9(4): 297-379.

Zimmermann H. 1907. Tierwelt am Strande der blauen Adria. Zeitschrift für Naturwissenschaften, Stuttgart 78: 293-322.

Zirpolo G. 1933. Zoobotryon verticillatum (Delle Chiaje). Mem. Pont. Acc. Sci., Nuovi Lincei, Roma 17: 190-441. 